\title{
Performances of Vegetable Type Pigeon Pea in Foothills of Nagaland
}

\author{
Malini B. Sharma* \\ Department of genetics and plant Breeding, SASRD, Nagaland University, \\ Medziphema 797106, India \\ *Corresponding author
}

Keywords

Vegetable pigeon pea, Performances

Article Info

Accepted:

20 October 2020

Available Online:

10 November 2020

\section{A B S T R A C T}

An experiment was conducted during kharif of 2018 at the research farm of School of agricultural research and rural development, Nagaland University, Medziphema to determine the performances of 12 vegetable type pigeon pea genotypes for 11 yield attributing traits under foothill conditions of Nagaland. The experiment was laid out randomized block design with 3 replications. The results showed significant differences for 5 traits viz., days $50 \%$ to flowering, primary branches, secondary branches, pods per plant and seeds per plot. BRG3 showed significant maximum number of seeds per pods and also exhibited highest green pod yield per plant. B3-13 showed maximum primary branches and also maximum pods per plant.

\section{Introduction}

Pigeonpea [Cajanus cajan (L.) Millsp], also known as arhar, tur and red gram, is nutritionally balanced and an exceptional source of protein in both green pea and dried grain (Faris and Singh, 1990). Along with protein, pigeonpea also renders carbohydrates and Vitamin A and C (Faris et al., 1987). Pigeonpea seeds are rich in proteins (generally within a range of 18 to $25 \%$ and as high as $32 \%)$, carbohydrates $(57.6 \%)$, fiber (1.5\%), minerals (3.5\%), amino acids, methionine and cysteine (Birk, 1993). Because of it rich source of protein, it is an ultimate addition to traditional cereal, banana or tuber-based diets of poor farmers that are protein deficient. Its ability to produce economic yield under limited moisture condition makes it an important crop of dryland agriculture. Pigeonpea represents about $5 \%$ of world legume production and more than $70 \%$ is being produced in India.

Pigeonpea is used in more diverse ways among the legumes even though it ranks sixth in area and production. It is a favourite crop of marginal farmers due to its multiple uses and roles in sustainable agriculture. It is also utilized as forage, fodder, fuel and medicine 
besides being a primary food. It also plays an important role in controlling soil erosion in erosion prone areas that are being caused by wind and water (Saxena, 2000).

Pigeonpea cultivars are grown for vegetable purpose, where pods are harvested at the milking to dough stage of its development. Most of the Indian consumers prefer green podded pigeonpea among the cultivars grown for vegetable purpose. These bring in better price than stripped ones, or pods of other colours. Green pigeonpea seeds have more nutritional value as compared to dal. Singh et al., (1984, 1983) and Singh (1988) reported that polysaccharides content was high in vegetable type pigeonpea with low content of crude fiber as compared to dal. The vegetable pigeonpea grains have higher crude fiber, fat, and protein digestibility. Normally in vegetable type sugar levels are around $5.0 \%$ but certain varieties such as ICP7035 has been identified by researchers at ICRISAT which a sugar content as high as $8.8 \%$.

Pigeonpea is not very popular across the globe. It is grown only as a backyard crop, an intercrop and sometimes for fencing purpose. Therefore there is not much agricultural statistics available in this crop. It is known as a poor man's crop grown only in very dry areas to sustain the poor farmers. However, subsequent research on this crop by plant breeders has transformed this semi- arid tropic crop into an adaptable and high yielding crop. It can be grown in high and low rainfall areas as it is resistant to diseases. This crop is a source of food, fuel, forage and enhances soil fertility due to its leguminous nature.

\section{Materials and Methods}

The experiment was carried out during kharif season in 2018 at the experimental farm of
School of Agricultural Sciences and Rural Development, Nagaland University, Medziphema campus, which is located at $23^{\circ}$ $45^{\prime} 49^{\prime \prime} \mathrm{N}$ latitude, $90^{\circ} 33^{\prime} 04$ " E longitude at an altitude of $305 \mathrm{~m}$ above sea level bearing sub-tropical climate.

The experimental material comprised of 12 pigeonpea genotypes collected from the University of Agricultural Sciences, Bangalore and ICRISAT, Hyderabad. The 12 genotypes were sown in a Randomized Block Design with three replications to obtain data on eleven different traits for yield and yield attributes. Spacing was maintained at $60 \mathrm{~cm}$ row to row and $30 \mathrm{~cm}$ plant to plant with plot length of $4 \mathrm{mtrs}$. Five randomly selected plants from each plot were taken for recording growth and yield parameters. The observations recorded on growth, yield and its attributes are presented in Table 1.

\section{Results and Discussion}

The results showed significant differences for traits viz., days $50 \%$ to flowering, primary branches, secondary branches, pods per plant and seeds per plot. ICP-7035 was earliest to flower while B1-66-1 took longest duration. B3-13 showed maximum primary branches while B1-169-1 had the maximum secondary branches. B3-13 also exhibited maximum pods per plant. BRG3 produced significant higher number of seeds per pods.

Though insignificant B2-106-1showed highest 100 green seed weight and the genotype BRG 3 performed highest with respect to green pod yield per plant.

Significant differences among 23 vegetable type Pigeon pea genotypes for the traits 100 green pod weight, 100 green seed weight, days to $50 \%$ flowering, and for number of primary branches per plant was also reported by Patil et al., (2016). Saroj et al., (2015) and 
Chethana et al., (2015) also reported significant variability in pigeon pea genotypes for traits like number of pods per plant, seed yield per plant, 100 seed weight and for other yield attributing traits.

Table.1 Performance of vegetable pigeon pea genotypes for yield and yield related traits in foothills of Nagaland

\begin{tabular}{|c|c|c|c|c|c|c|c|c|c|}
\hline Characters & $\begin{array}{c}\text { Plant } \\
\text { height } \\
\text { Genotypes }\end{array}$ & $\begin{array}{c}\text { Days } \\
\text { 50\% to } \\
\text { Flowering }\end{array}$ & $\begin{array}{c}\text { Primary } \\
\text { branches }\end{array}$ & $\begin{array}{c}\text { Sec. } \\
\text { branches }\end{array}$ & $\begin{array}{c}\text { Pods } \\
\text { /cluster }\end{array}$ & $\begin{array}{c}\text { Pods/ } \\
\text { plant }\end{array}$ & $\begin{array}{c}\text { Seeds/ } \\
\text { pods }\end{array}$ & $\begin{array}{c}\text { 100 seed } \\
\text { (green) } \\
\text { weight } \\
\text { (g) }\end{array}$ & $\begin{array}{c}\text { Green } \\
\text { pod yield/ } \\
\text { Plant } \\
\text { (g) }\end{array}$ \\
\hline B1-66-1 & 250.80 & 168.67 & 27.80 & 109.00 & 1.33 & 39.70 & 4.67 & 24.86 & 313.20 \\
\hline B3-13 & 231.74 & 167.00 & 34.37 & 124.00 & 2.00 & 85.90 & 4.33 & 21.31 & 231.63 \\
\hline B2-5-2-1 & 246.40 & 167.33 & 32.20 & 94.60 & 1.67 & 64.17 & 5.00 & 22.77 & 249.48 \\
\hline B1-141-1 & 207.60 & 166.67 & 27.57 & 108.63 & 1.67 & 50.80 & 4.67 & 22.60 & 327.37 \\
\hline B1-51 & 192.60 & 167.33 & 30.60 & 91.80 & 1.67 & 44.73 & 4.33 & 20.74 & 156.26 \\
\hline BRG-2 & 217.81 & 166.67 & 34.00 & 106.60 & 1.33 & 48.47 & 5.00 & 23.87 & 225.30 \\
\hline B2-10 & 200.73 & 167.00 & 28.60 & 93.20 & 1.67 & 30.87 & 4.33 & 23.57 & 280.36 \\
\hline BRG1 & 173.97 & 166.33 & 16.40 & 44.80 & 1.33 & 17.27 & 4.67 & 24.31 & 440.99 \\
\hline BRG3 & 158.40 & 167.67 & 14.77 & 33.00 & 1.33 & 30.43 & 5.33 & 24.11 & 483.80 \\
\hline B1-169-1 & 242.77 & 167.67 & 33.00 & 166.60 & 1.33 & 54.70 & 4.33 & 25.01 & 133.72 \\
\hline B2-106-1 & 210.60 & 166.00 & 33.57 & 165.43 & 2.33 & 74.20 & 3.67 & 27.24 & 288.25 \\
\hline ICP-7035 & 210.00 & 156.00 & 22.20 & 75.40 & 1.33 & 22.20 & 5.00 & 23.50 & 331.78 \\
\hline G- Mean & $\mathbf{2 1 1 . 9 5}$ & $\mathbf{1 6 6 . 1 9}$ & $\mathbf{2 7 . 9 2}$ & $\mathbf{1 0 1 . 0 9}$ & $\mathbf{1 . 5 8}$ & $\mathbf{4 6 . 9 5}$ & $\mathbf{4 . 6 1}$ & $\mathbf{2 3 . 6 6}$ & $\mathbf{2 8 8 . 5 1}$ \\
\hline C.D-5\% & - & 3.03 & 6.05 & 24.73 & - & 12.86 & 0.86 & - & - \\
\hline C.D-1\% & - & 4.11 & 8.22 & 33.61 & - & 17.48 & 1.16 & - & - \\
\hline S.E & 20.64 & 1.03 & 2.06 & 8.42 & 0.33 & 4.39 & 0.29 & 1.48 & 110.88 \\
\hline
\end{tabular}

\section{Acknowledgement}

The author is grateful to Nagaland university, Medziphema for providing necessary facility during research and also to University of Agricultural Sciences, Bangalore and ICRISAT, Hyderabad for providing the materials.

\section{References}

Birk Y. 1993. Anti-nutritional factors (ANFs) in lupin and other legume seeds: Pros and cons. in Advances in lupin research (Martins and da Costa, eds.). Proceedings of the 7th Lupin Conference held at Evora, Portugal. pp 424-429

Chethana, C. K. D., Harmaraj, P. S., Muniswamy, S., Yamanura, Gangadhara, K. and

Nagaraju, C. H. 2015. All India Co-ordinated Research Project on Pigeonpea, Agricultural Research. Trends in Biosciences. 8(1).

Faris D G, Saxena KB, Mazumdar S and 
Singh U. 1987. Vegetable Pigeonpea: A promising Crop for India. ICRISAT, Patancheru, A.P., India. pp. 3.

Faris D G and Singh U. 1990. Pigeonpea: Nutrition and Products. In: Nene YL, Hall SD,

Shiela VK (Eds.) The Pigeonpea. ICRISAT, Patancheru 502 324, A.P. India. CAB International, U.K. pp. 401-433.

Patil, H. E., Dikshit, N., Aklade, S. A. and Vavdiya, P. A. 2016. Evaluation of vegetable type pigeonpea (Cajanus cajan (L.) genotypes for yield and yield contributing traits. Ecology, environment and conservation paper. 22: 247-254.

Saroj, S.K., Singh, R.S., Singh, M. and Pathak, N. 2015. Studies on genetic variability of parents, F1,'S and F2,'S populations in pigeonpea. Agricultural for Sustainable Development. 3(1): 32-
36.

Saxena K B. 2000. Pigeonpea in China. International Crops Research Institute for the Semi Arid Tropics, Patancheru 502 324, A.P. India. pp. 29.

Singh, U; Jain, K. C., Jambinathan, R. and Faris D. G. 1983. Nutritional quality of vegetable pigeonpea (Cajanus cajan). Dry matter accumulation, carbohydrates and protein. Journal of Food Science. 49: 799-802.

Singh, U., Jain, K. C., Jambinathan, R. and Faris D. G. 1984. Nutritional quality of vegetable pigeonpea (Cajanus cajan). Mineral and trace elements. Journal of Food Science. 49: 645-646.

Singh, U. 1988. Anti-nutritional factors of chickpea and pigeonpea and their removal by processing. Plant and Foods Human Nutrition. 38: 251-261.

\section{How to cite this article:}

Malini B. Sharma. 2020. Performances of Vegetable Type Pigeon Pea in Foothills of Nagaland. Int.J.Curr.Microbiol.App.Sci. 9(11): 2587-2590. doi: https://doi.org/10.20546/ijcmas.2020.911.313 